\title{
Groundwater Conditions and the Geoenvironmental Impacts of the Recent Development in the South Eastern Part of the Western Desert of Egypt
}

\author{
Ahmed Aziz Abdel Moneim¹, Sameh Zaki², Maghawri Diab ${ }^{3}$ \\ ${ }^{1}$ Faculty of Science, Sohag University, Sohag, Egypt \\ ${ }^{2}$ The Egyptian Mineral Resources Authority, Cairo, Egypt \\ ${ }^{3}$ Faculty of Science, Minofiya University, Menufia, Egypt \\ Email: ahmed aziz9791@science.sohag.edu.eg
}

Received 22 January 2014; revised 21 February 2014; accepted 19 March 2014

Copyright @ 2014 by authors and Scientific Research Publishing Inc.

This work is licensed under the Creative Commons Attribution International License (CC BY). http://creativecommons.org/licenses/by/4.0/

\section{Open Access}

\section{Abstract}

The area to the southeast of the Western Desert of Egypt has been subjected to considerable development activities over the last few years. The development includes the cultivation of about $2260 \mathbf{~ k m}^{2}$ of the desert lands "the well-known Toshka Project". The hydrogeological conditions of the area are subjected to detailed investigation based upon the construction of the water table maps, hydrologeologic cross-sections, pumping tests, aquifer geometry, and recharge-discharge relationship. The study revealed that the Quaternary and the Nubia sediments are the main water bearing layers in the area. The Quaternary aquifer is of limited potential and made of mixed sand with clay deposit ranges in thickness between 5 to $10 \mathrm{~m}$. The Nubia aquifer is the oldest sedimentary formation and the main groundwater resources in the area. It is represented by multilayered of sand and silt exists generally under artesian conditions. It is composed of three water bearing horizons partially separated by two confining horizons and extends in thickness ranges between $\mathbf{7 0}$ and 230 meters. The thickness increases away from the high dam lake. The analysis of pumping tests of the aquifer indicated that its potentiality is increasing north of the High Dam Lake (HDL) whereas it decreases in the other direction. This is due to high hydraulic conductivity and aquifer thickness in the area northeast of Khor Toshka and at west of Garf Hussein. The hydraulic conductivity of the aquifer ranges between 12.73 and $0.9 \mathrm{~m} / \mathrm{day}$. The review of the changes in groundwater levels in the area showed that there is a drop in ranges between 1 and 14 meters in the last few years indicating that the extraction from the groundwater is much more higher that the replacement rate. Also, the analysis of the fluctuation of water levels of the HDL and the groundwater level indicated that the influence of water on groundwater level in the area is observed only at a distance less than $10 \mathrm{~km}$ from the lake shore line. Seepage from the HDL is estimated as $238.13 \times 10^{6}$ 
$\mathrm{m}^{3}$ /year. The geo-environmental impacts of the development on the surface water and groundwater in the area are evaluated.

\title{
Keywords
}

\author{
Toshka Project; Groundwater; Aswan High Dam Lake (Nasser Lake); Aquifer Potentiality; \\ Geo-Environmental Impacts
}

\section{Introduction}

The study area occupies the southeastern corner of the Western Desert of Egypt covering an area of $45580 \mathrm{~km}^{2}$. It is located in the west of the High Dam Lake (HDL), between latitudes $22^{\circ} 00^{\prime}-24^{\circ} 00^{\prime} \mathrm{N}$ and longitudes $30^{\circ} 30^{\prime}$ $33^{\circ} 00^{\prime} \mathrm{E}$ (Figure 1). It is limited from the east by the shore line of High Dam Lake (HDL). The area has been subject to enormous form of land reclamation project that is called south Valley Development Project (Toshka project). This project aims at reclamation of about $2260 \mathrm{~km}^{2}$ (500,000 feddan) in its primary stage and construction of huge pumping station to transfer the water from the HDL through El Sheikh Zaid canal that feeds four main distributing canals. This in addition to drilling of few productive groundwater wells. The project involves pumping of around 25 million $\mathrm{m}^{3} /$ day. The main pump station located on the left bank of High Dam Lake about $8 \mathrm{~km}$ north of Toshka spillway. The pump station is designed to lift water from the Lake to Sheikh Zaid main canal with maximum static column of $52.5 \mathrm{~m}$ to cover the difference between the lowest level of lake storage at elevation $147.5 \mathrm{~m}$ and the main canal water level at elevation 200 meters. At the end of the canal it is divided into two main sub-canals extending for $22.20 \mathrm{~km}$ and $18.40 \mathrm{~km}$ respectively. The first sub-canal is subdivided into two branches, namely 1 and 2 to the north with length $24 \mathrm{~km}$ each. The second sub-canal is also divided into two branches namely 3 and 4 to the south with length $23.30 \mathrm{~km}$ and $59.50 \mathrm{~km}$ respectively (Figure 2).

The present work aims at clarify the hydrogeological conditions and geo-environmental impact of such development on the water resources in the area. These resources include the surface water of High Dam Lake and the groundwater conditions in the area. To achieve the goals of the present study, many data were collected from different sources as well as the field studies. The present study included the evaluation of the aquifer characteristics, their potentiality and hydraulic parameters based on the results of the pumping tests carried out in the fourteen production wells in the area. Fluctuations of water level (surface and groundwater) over the last few years were analyzed to investigate the hydraulic relation between surface and groundwater as well the estimation of the seepage loss from the High Dam Lake.

The study area belongs to the arid region of North Africa where it is generally characterized by long hot summer and worm winter with very low rainfall. Occasional rain may take place on the area (e.g. $27^{\text {th }}$ May 1988). The mean air temperature ranges between $14.1^{\circ} \mathrm{C}$ and $38.3^{\circ} \mathrm{C}$, while the monthly average of relative humidity in the study area varies greatly from $25 \%$ to $58 \%$ in winter and summer respectively. The evaporation is a function of the air temperature, air humidity and wind speed that affects largely the surface water in HDL while the water loss is very limited on the groundwater as the depth extends beyond the effect of evaporation. The evaporation from surface water body is high in summer season reaching up to $13.3 \mathrm{~mm}$ from the lake and low in winter.

\section{Geomorpholgy of the Area}

Geomorphologically the study area is distinguished into six geomorphological units [1] [2] (Figure 3) as follows:

Denudational landforms, which are classified into higher Limestone Plateau; Lower Nubia El Shab and Adindan Sandstone Pediplains; Residual Hills that comprise sandstone hills capped by carbonate beds e.g. Bargat El Shab, El Nabta, Barg El Sahab, representing relics of the retreating Limestone Plateau.

Structural denudational landforms includes Garf Hussein-Kalabsha hummocky fault blocks; fault ridges; Chephren Quarries_-Kom Ombo arch, Um Shaghir dome; El Kaser syncline; El Sana domes and basins; El Soda up lift; El Hamra uplift; Plateau basin and Marawa basin.

- Fluvial landforms include the today drainage system, inverted wadis and terraces.

- Volcanic landforms include volcanic hills and dykes. 


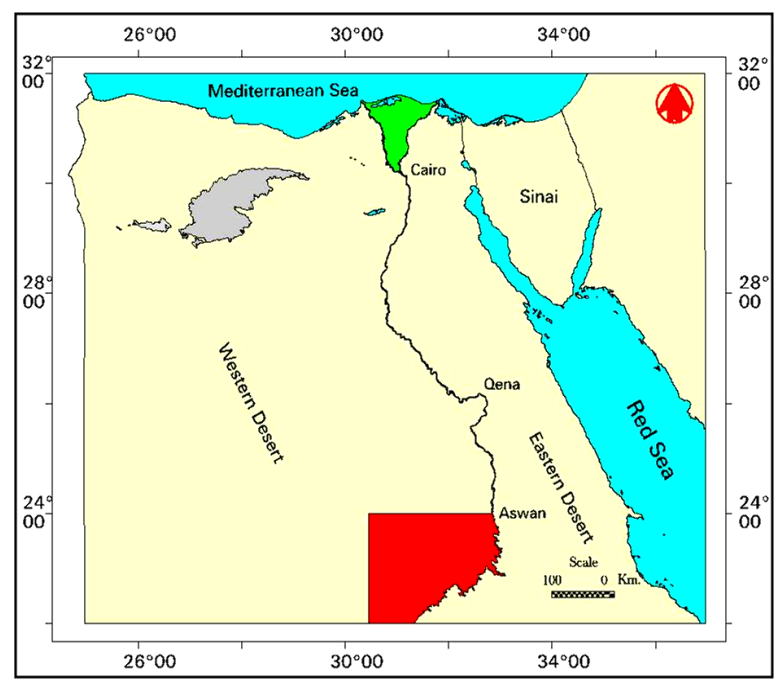

Figure 1. Location map of the study area.

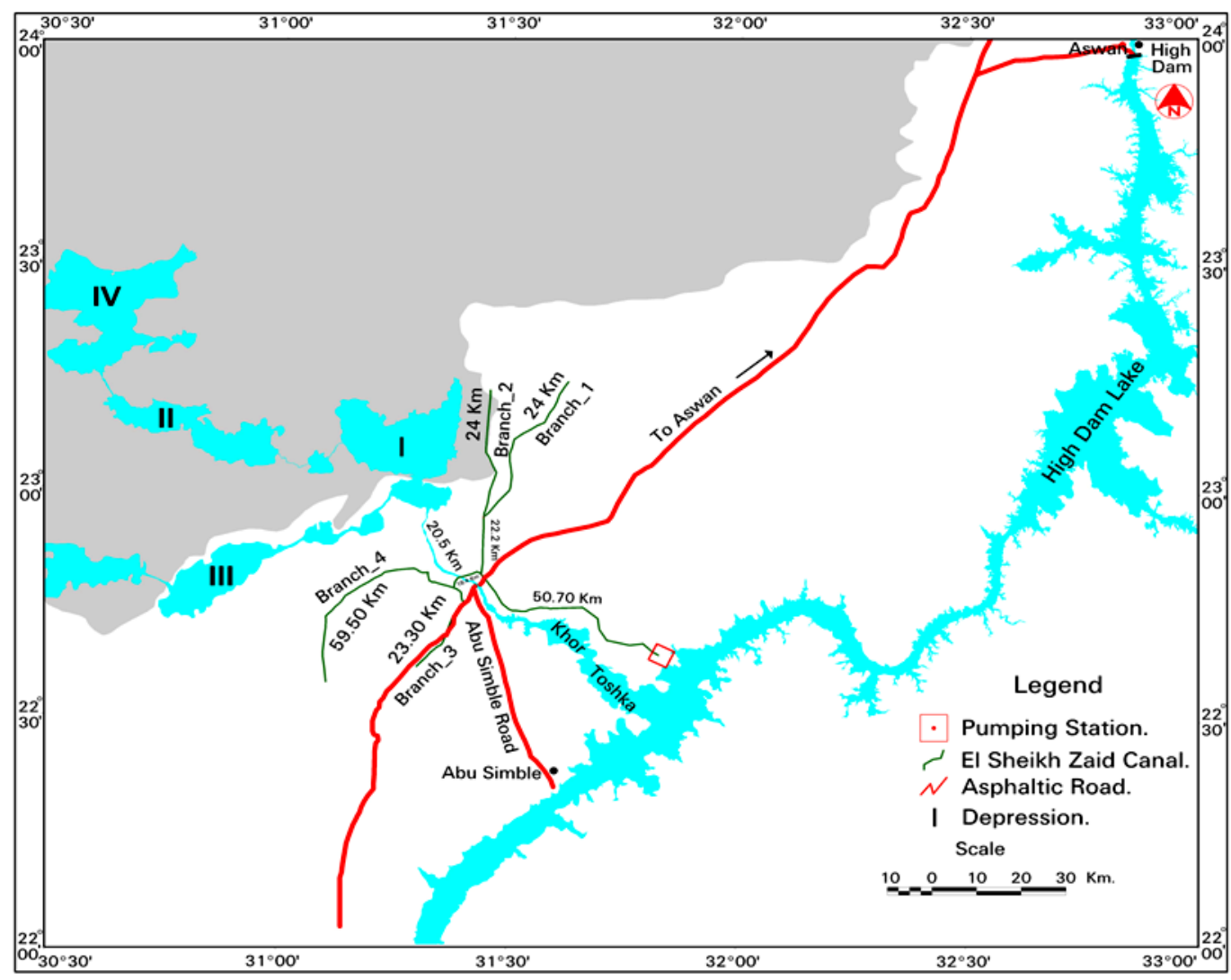

Figure 2. The system of canals in Toshka project.

- Landforms related to groundwater with spring mounds.

- Aeolian landforms include active sand dune; sand sheet and ripples, alluvial Hamada and lag Hamada.

\section{Geologic Setting}

The rock units in the area are represented by the basement rocks that are overlain by the sedimentary succession 


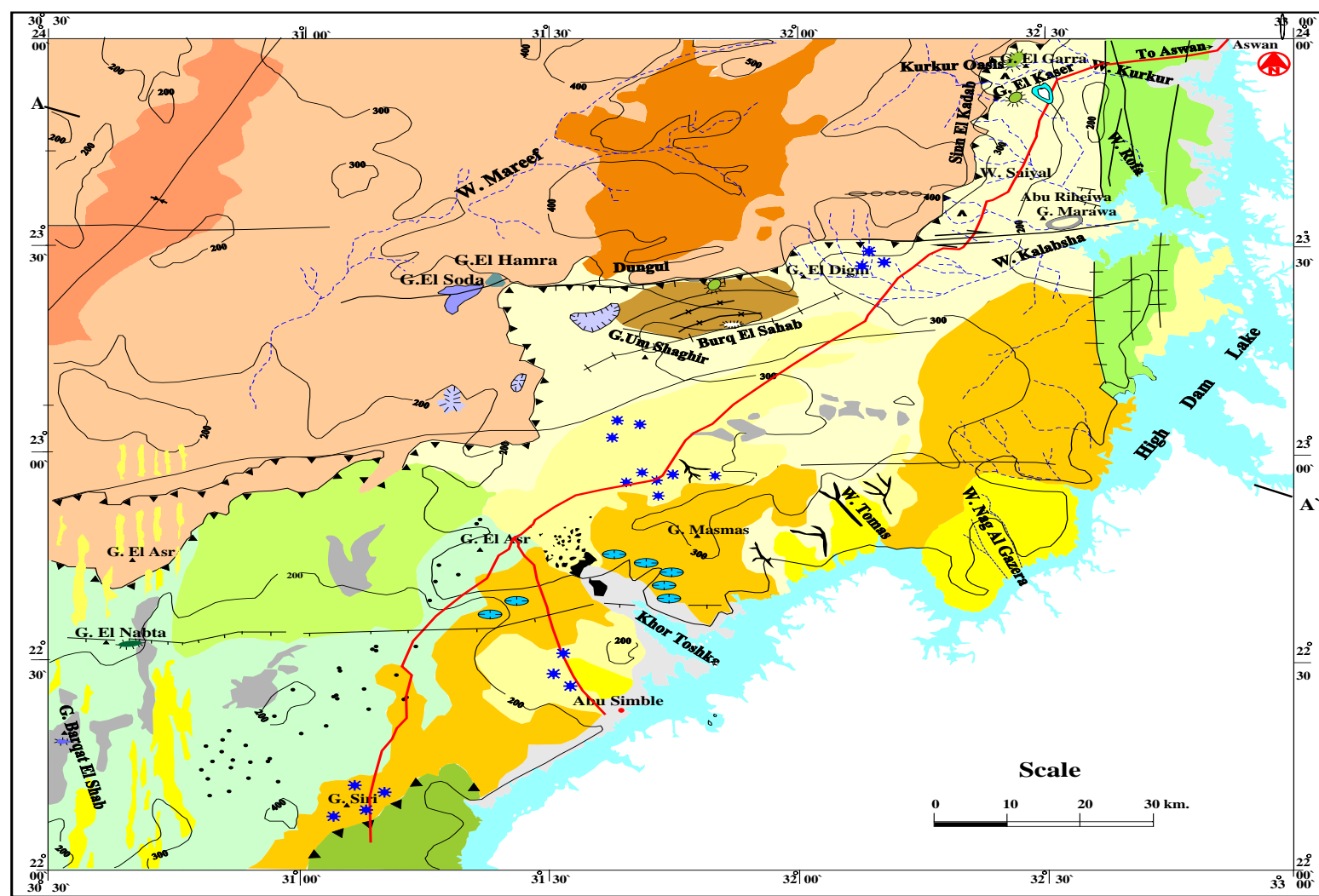

\section{LEGEND}

\section{Denudational Landforms}

Higher Limestone Plateau, Highly Dissected by Faults. Lower Sandstone Plateau, Moderatly Dissected by Wadies. Pediplain

Nubia Pediplain $(190$ - $260 \mathrm{~m}$.)

El-Shap Pediplain. $(250$ - $300 \mathrm{~m}$.)

Adindan Pediplain (200 - $250 \mathrm{~m}$.)

Residuall Hills

萧 Residual Sandstone Hills ( Inselberg Type ).

齐 Residual Hills capded by Carbonate beds.

$\square$ El Malki Inverted Sandstone Irregular Hills.

Denudational Solpes.

Depression.

\section{Structural Denudational Landforms}

Garf HusseinKalabsha Humnocky Fault Blocks.

Fault Ridges.

Chephren Quarries - Kom Ombo Arch.

Um Shaghir Dome.

El Kaser Syncline.

El Sana Domes and Basins.

El Soda Uplift (Anticline).

El Hamra Uplift (Anticline).

Plateau Basin.

Marawa Basin.

\section{Fluvial Landforms}

L7 Today Drainage Lines.

I Inverted Wadis.

$\Lambda \quad$ Terrace.

Volcanic Landforms

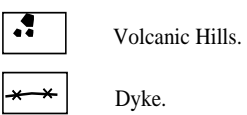

Landforms Related to Groundwater.

$\bigcirc \quad$ Spring Mounds.

\section{Aeolian Landforms}

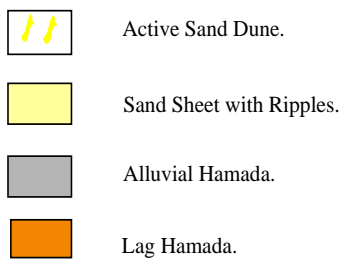

Detalied Geomorphology

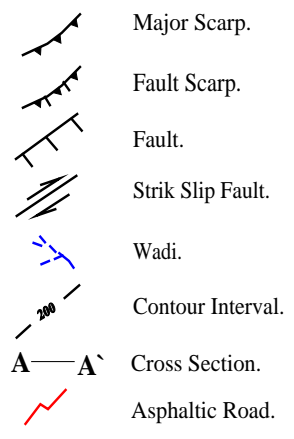

Figure 3. Geomorphological map of the study area. 
(Figure 4). The basement rocks are represented by granites, granodiorite and gneiss. The sedimentary rocks exposed in the area include wide area covered by Paleozoic to Cenozoic rocks. The Paleozoic rocks include Devonian Wadi Malik and Carboniferous Gilf formations, Jurassic Cretaceous rocks comprising Upper JurassicLower Cretaceous Abu Ballus Formation, Cenomanian El Burg, Bahariya Formations, Upper Cretaceous Nubia Formation and the lower beds of the Dakhla Formation. The Cenozoic units are classified into the upper beds of the Dakhla, Kurkur Formation, Garra Formation and Dungul Formation, and the Oligocene volcanic. On the top of the succession there is the Quaternary deposit that covers large areas and includes piedmont gravels, Tufa, fresh water limestone, calcite deposits, playa deposits sand dune and sand sheets [3]-[7].

Structurally the area is dominated by extensional tectonics in a stretch of $350 \mathrm{~km}$ from N to S and of over 700 $\mathrm{km}$ from $\mathrm{E}$ to W. Some of the faults herein extend for huge distances in-between the Red Sea and the Atlantic Ocean, e .g. Guinea-Nubia lineament [8]. Along some of these mega faults, crustal seismicity is high along with volcanicity in the area, extend through a long span of time in-between the Cambrian and Recent. The dominant seismicity of this region is a result of ruptures occurring along distinct fault systems [9].

In the study area structural pattern is classified into two main categories; faults and folds, which greatly shaped the geomorphological features of the study area (Figure 5). Such effect led to the formation of Dungul-Kurkur Plateau in the north and El Shap-Adindan Nubia Pediplain to the east, west and central part. Faults are originally normal faults but accompanied or inverted later by strike slip movements [10] [11]. They follow the E-W, ENE-WSW, N-S, NE-SW and NW-SE trends. The E-W faults are the most important in the study area and nearly affect the whole even the Quaternary deposits. Occasionally, the faults bifurcate and swing their courses to ENE-WSW. Commonly, they are accompanied with small folding along the fault strike well seen along the Plateau E-W fault; The N-S faults dominate the northeastern and northern parts of the area displacing the E-W faults. They are associated with horizontal displacement and classified into two groups; North Kalabsha group and South Kalabsha group. The NE-SW and NW-SE faults trends are relatively fewer in number and affect the pre-existing faults. They are characterized by horizontal displacements along their courses, whereas the NW-SE is dominantly normal dip slip faults. Kalabsha faults include several genetic types' characters. It starts in the pediment surface as normal changing into sicor whereas below Gabal Kalabsha the fault is reversal.

\section{Groundwater Conditions}

The water bearing formations in the area are represented by the two main aquifers; the Quaternary and the Nubia aquifer. In order to investigate hydrogeological conditions in the study area, the available hydrogeological data were collected and investigated. The data include lithology of the existing wells, water table data, extraction data, and seasonal depth to water table, etc. The result of the collected data is subjected to detailed review, organized and analyzed to revel the hydrogeological conditions on the area and to monitor the geo-environmental impact of the project on the groundwater and the HDL in the area.

\subsection{Quaternary Aquifer}

The Quaternary aquifer is composed of sandy facies mixed with clay deposits; it is of reduced thickness, ranges between 5 and $10 \mathrm{~m}$. The groundwater of this aquifer is of limited quantity and therefore the Quaternary aquifer is of little hydrological importance. The number of drilled wells tapping this aquifer is limited and accordingly the available data about the Quaternary aquifer are also limited.

\subsection{Nubia Aquifer}

The Nubian aquifers underline southeast Egypt and also exist in Libya, Chad and Sudan. The aquifer is unconfined in the western part of the western desert of Egypt (east Oweinat) but not in the entire Nubian region. [12], pointed out that the sandstone is highly porous with an average bulk porosity of $20 \%$, exceeding any secondary porosity introduced by fracturing. [13] suggested that the groundwater of the Nubian aquifer system is fossil water that infiltrated locally in the past and that groundwater surface slops to the NE, indicating inflow across the Libyan and Sudan borders to the Egyptian depressions. [14] also concluded that the groundwater formed from in situ precipitation during the Late Pleistocene to Eary Holocene times. Using environmental isotopes and Hydrogeochemical techniques they determined that the main bulk of water is "fossil" and that contributions from recent recharge are insignificant. For more detailed study of the Nubian aquifer system in the western desert, are available in [15]-[21]. 


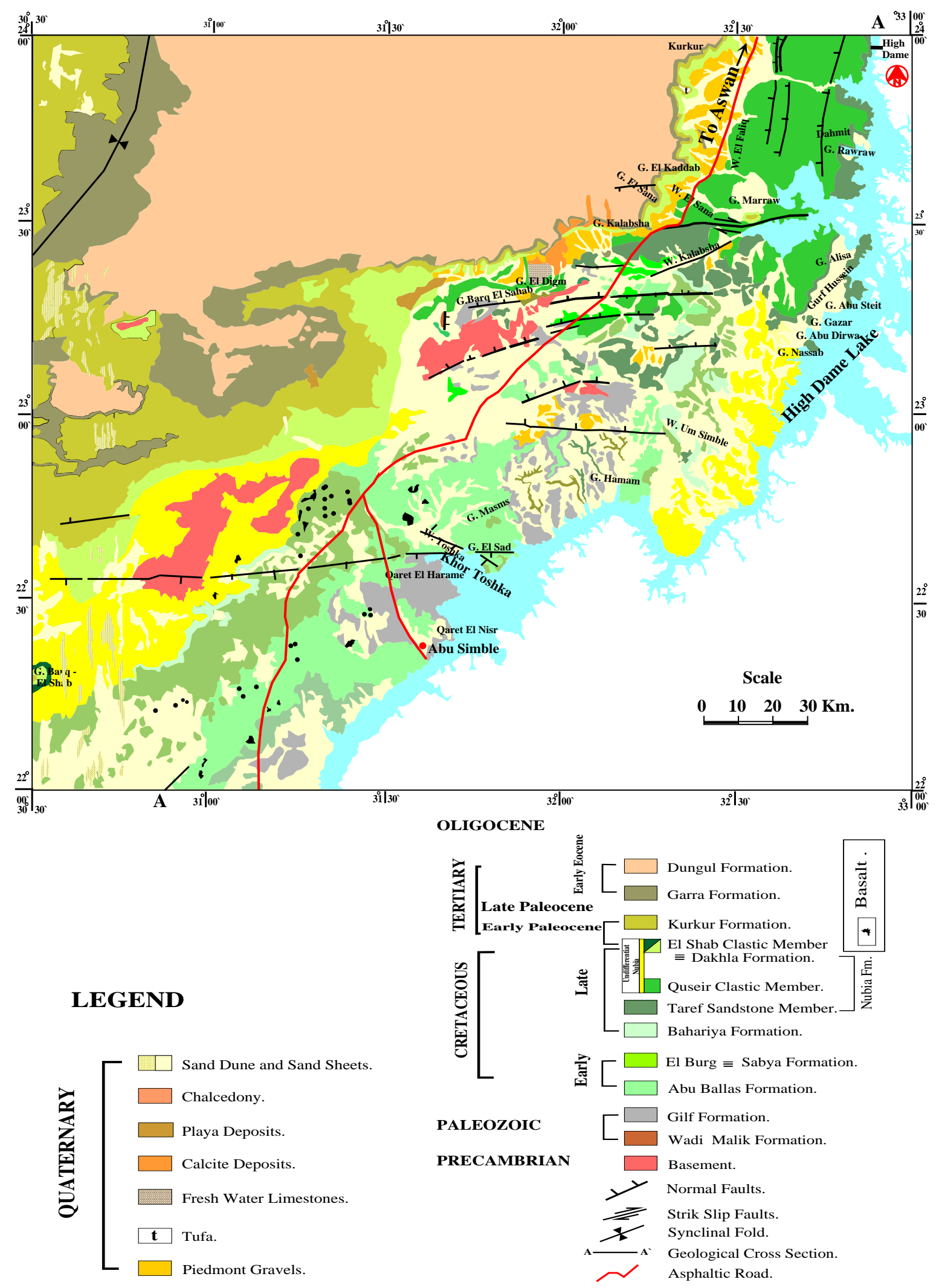

Figure 4. Geological map of the study area (compiled from [7] with modification). 


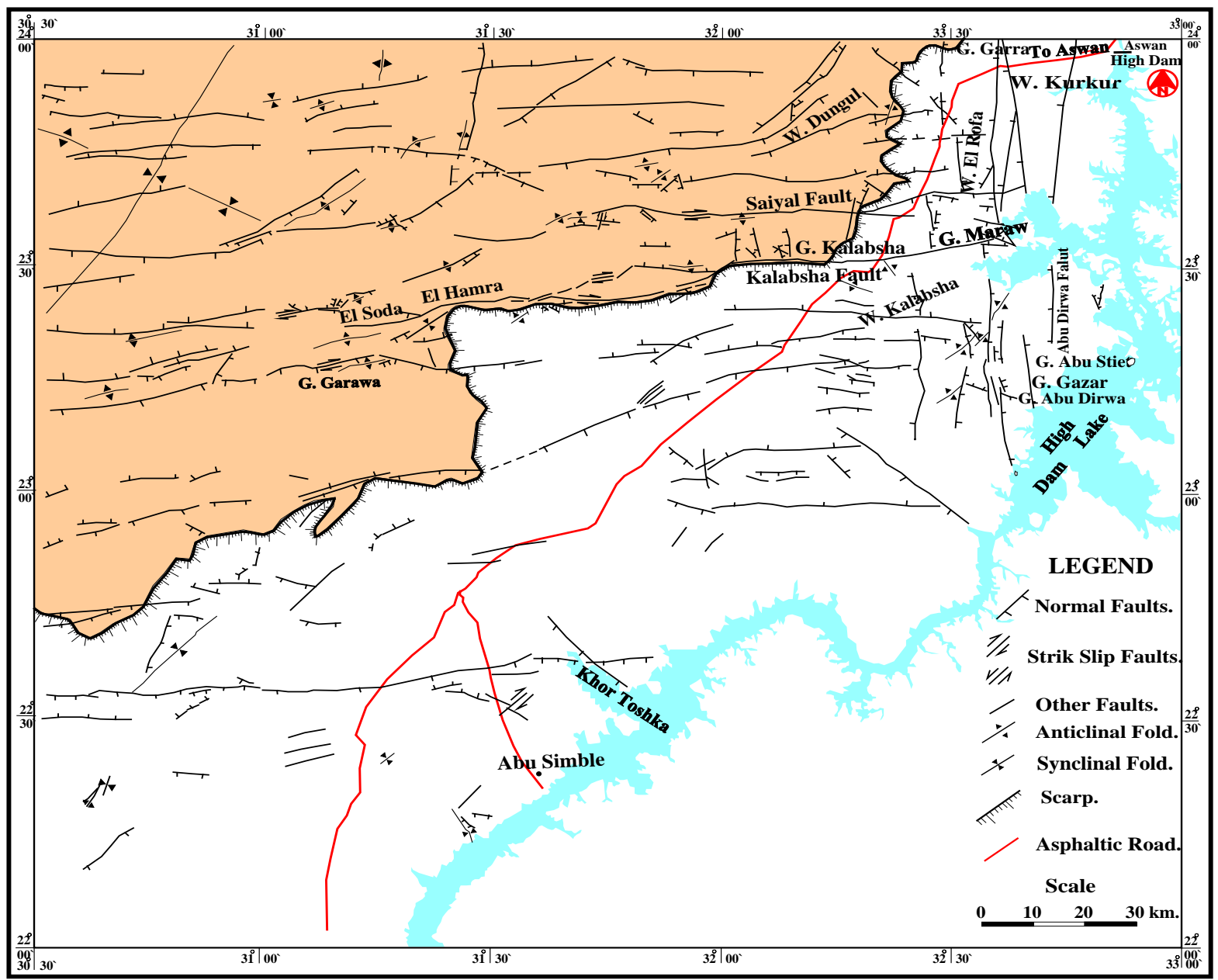

Figure 5. Structural map of the study area (compiled from [3] [4] [5] with some modifications).

Based upon the lithology of the drilled wells in the area, four hydrogeological cross-sections were made (Figure 6). The review of these sections indicated that groundwater in the Nubian aquifer resides in continental sandstone that unconformable overlies basement rocks and is covered by Quaternary deposits. It is the main groundwater aquifer system in the area and composed mainly of sand, sandstone intercalated with clay. The aquifer is of multilayered nature and represents the eastern fringes of the multilayered artesian aquifer of the Western Desert of Egypt. In Toshka, the aquifer system is composed of three horizons partially separated by two confining horizons. The first horizon belongs to the Qusier Clastics, Upper Member of the Nubia Formation (it crops out in the area southwest of Aswan at the foot slope of the Sin El Kaddab scarp and stretches to the Nile bank). The thickness of this horizon is $40 \mathrm{~m}$ in the north and $100 \mathrm{~m}$ in southwest as shown in section A-A' (Figure 7), whereas its thickness is about $20 \mathrm{~m}$ to the east and $50 \mathrm{~m}$ to the west as shown in section B-B' (Figure 8) and ranging between $50 \mathrm{~m}$ and 70 as shown in section C-C' (Figure 9) but it ranges between $40 \mathrm{~m}$ and $60 \mathrm{~m}$ in section D-D' (Figure 10).

The second horizon belongs to the Taref Sandstone the lower member of the Nubia Formation (it crops out at the scarp base between Gabal Derwa and Aswan Gharb village). This horizon is composed mainly of sandstone with minor varicolored clay intercalations. The thickness of the Taref Sandstone varies from $110 \mathrm{~m}$ in the northeast (Khor Galal well) to $140 \mathrm{~m}$ to the southwest (well no. 59) as shown in cross section A-A-; whereas it ranges from 140 to $130 \mathrm{~m}$ as shown in cross section B-B' and C-C' respectively and ranging between $80 \mathrm{~m}$ and $130 \mathrm{~m}$ as shown in section D-D'. The third horizon belongs to the Mesozoic-Paleozoic undifferentiated sandstones. This horizon overlies directly the basement complex. The thickness of this horizon is about $70 \mathrm{~m}$ and extends northeast to southwest as indicated in the cross sections (Figure 7 and Figure 8 and Figure 10) and 


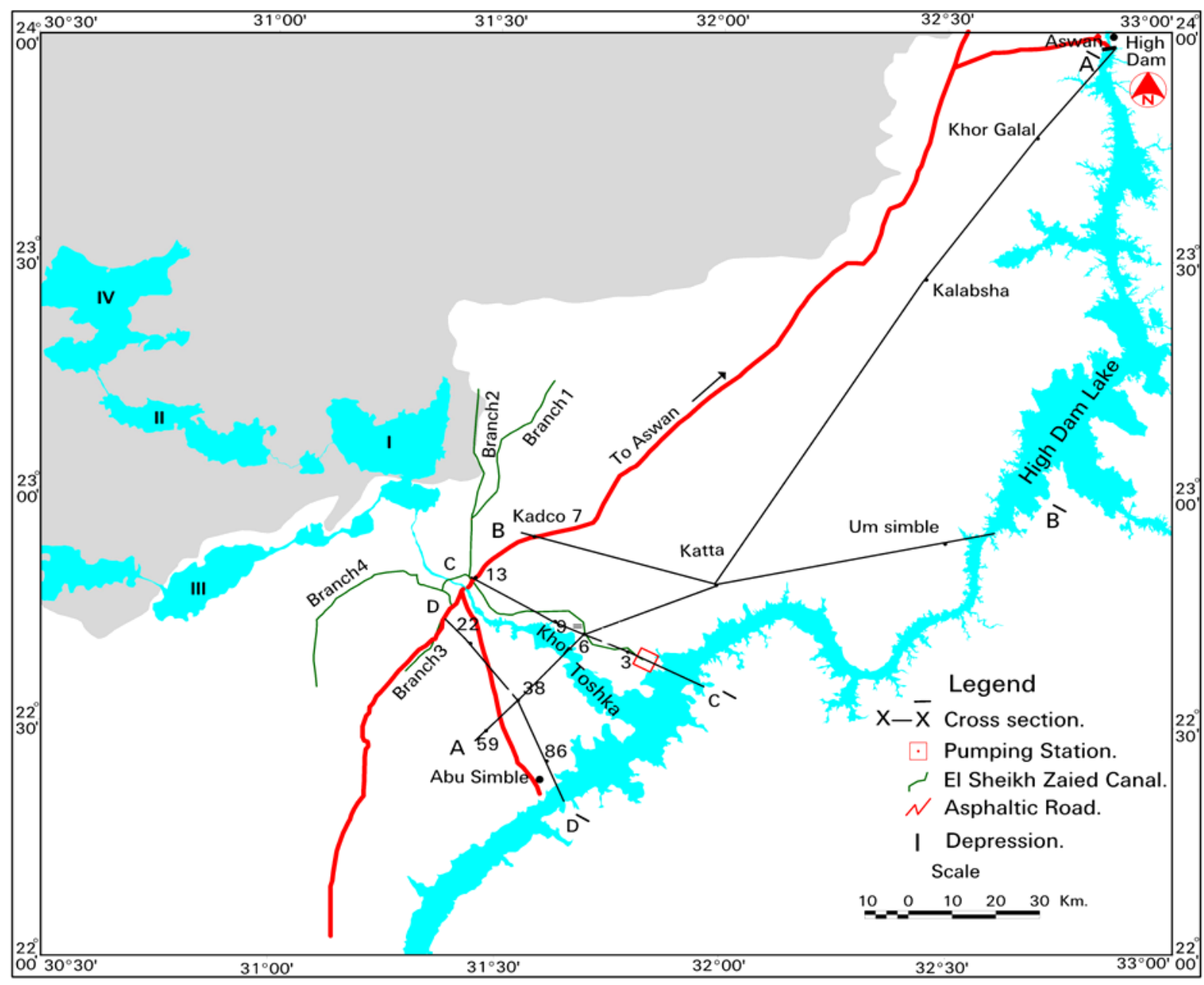

Figure 6. Location map of hydrogeological section.

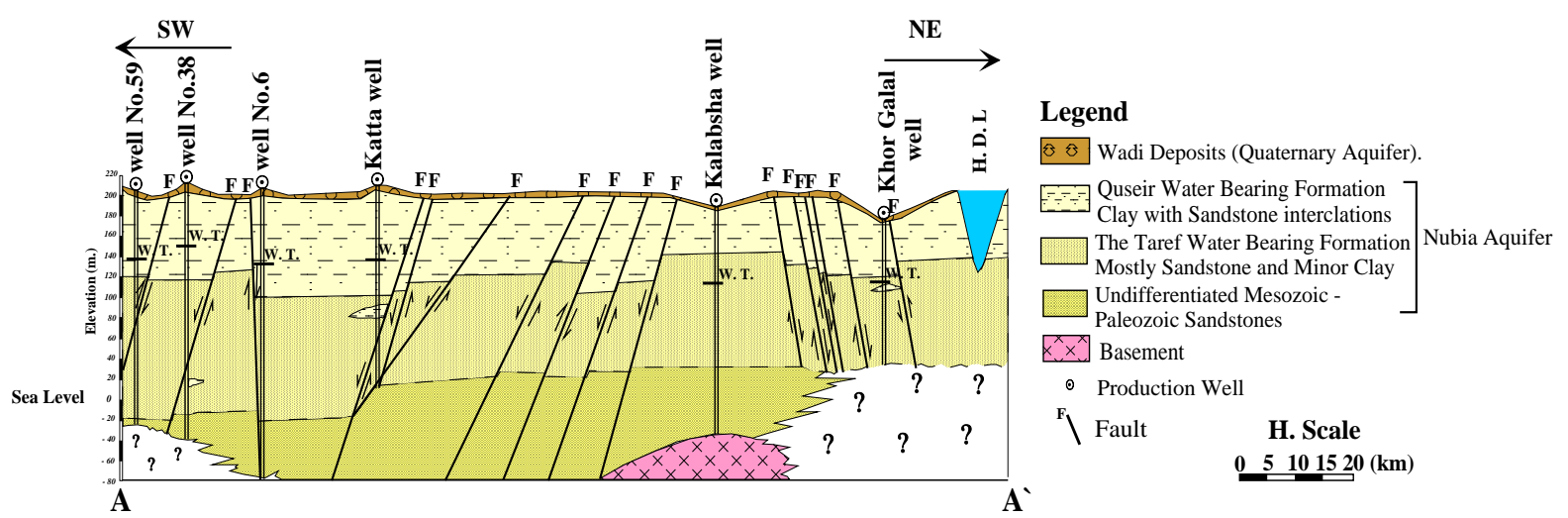

Figure 7. Hydrogeological Cross Section (A-A').

ranging between $40 \mathrm{~m}$ and $100 \mathrm{~m}$ (northwest southeast) as shown in cross section (C-C')

The result of hydrogeological investigations indicates that the water level in the wells tapping this horizon ranges between 112.5 m.a.s.l at Kalabsha well and 150.85 m.a.s.l at well no. 38 (SW) and 112.14 m.a.s.l to 145.64 at Kadco7 = and Um Simble well, respectively as shown in (Figure 7 and Figure 8), whereas; the water level ranges from 115.2 m.a.s.l to 144.04 m.a.s.l at well no.13 and well no. 3 respectively (Figure 9) and ranges 


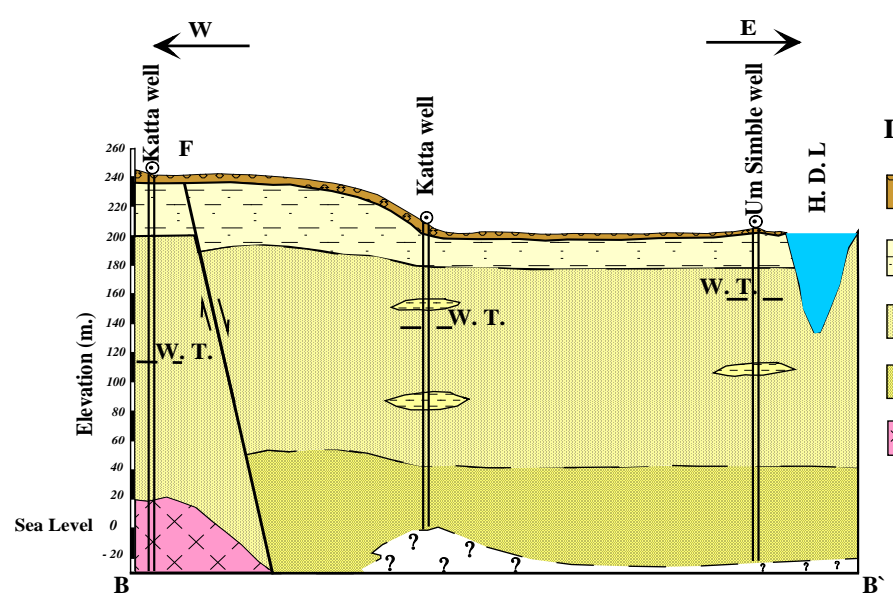

Legend

Wadi Deposits (Quaternary Aquifer).

Quseir Water Bearing Formation Clay with Sandstone interclations

The Taref Water Bearing Formation Nubia Aquifer Mostly Sandstone and Minor Clay

Undifferentiated Mesozoic -

Paleozoic Sandstones

Basement

- Production Well

F Fault H. Scale

Figure 8. Hydrogeological cross section (B-B').

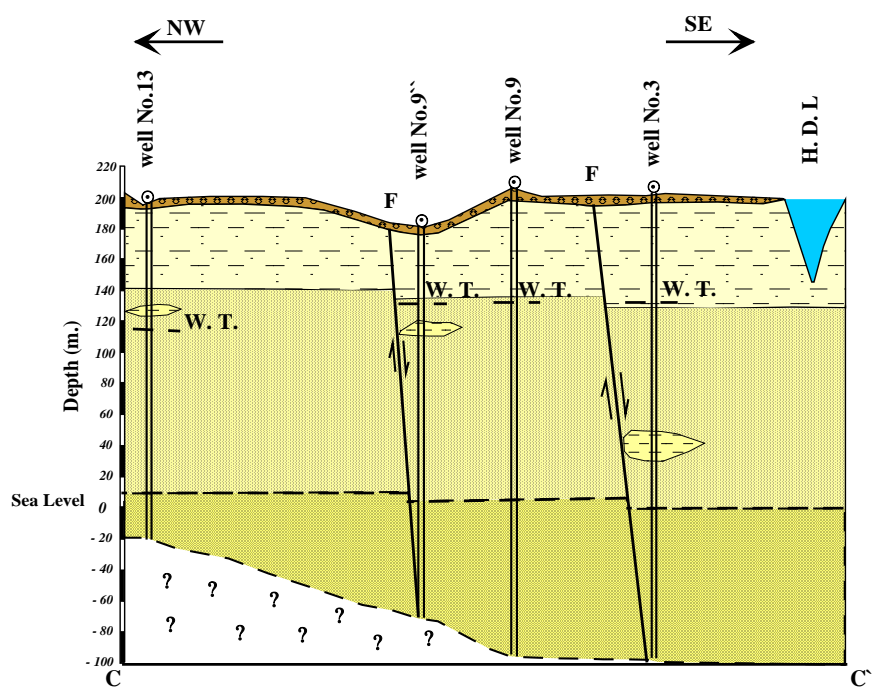

\section{Legend}

\& 0 Wadi Deposits (Quaternary Aquifer).

Q_- Quseir Water Bearing Formation Clay with Sandstone interclations The Taref Water Bearing Formation Mostly Sandstone and Minor Clay

Undifferentiated Mesozoic Paleozoic Sandstones

- Production Well

F Fault

$\begin{array}{llll}0 & 5 & 10 & (\mathrm{~km} .)\end{array}$

Figure 9. Hydrogeological cross section (C-C').

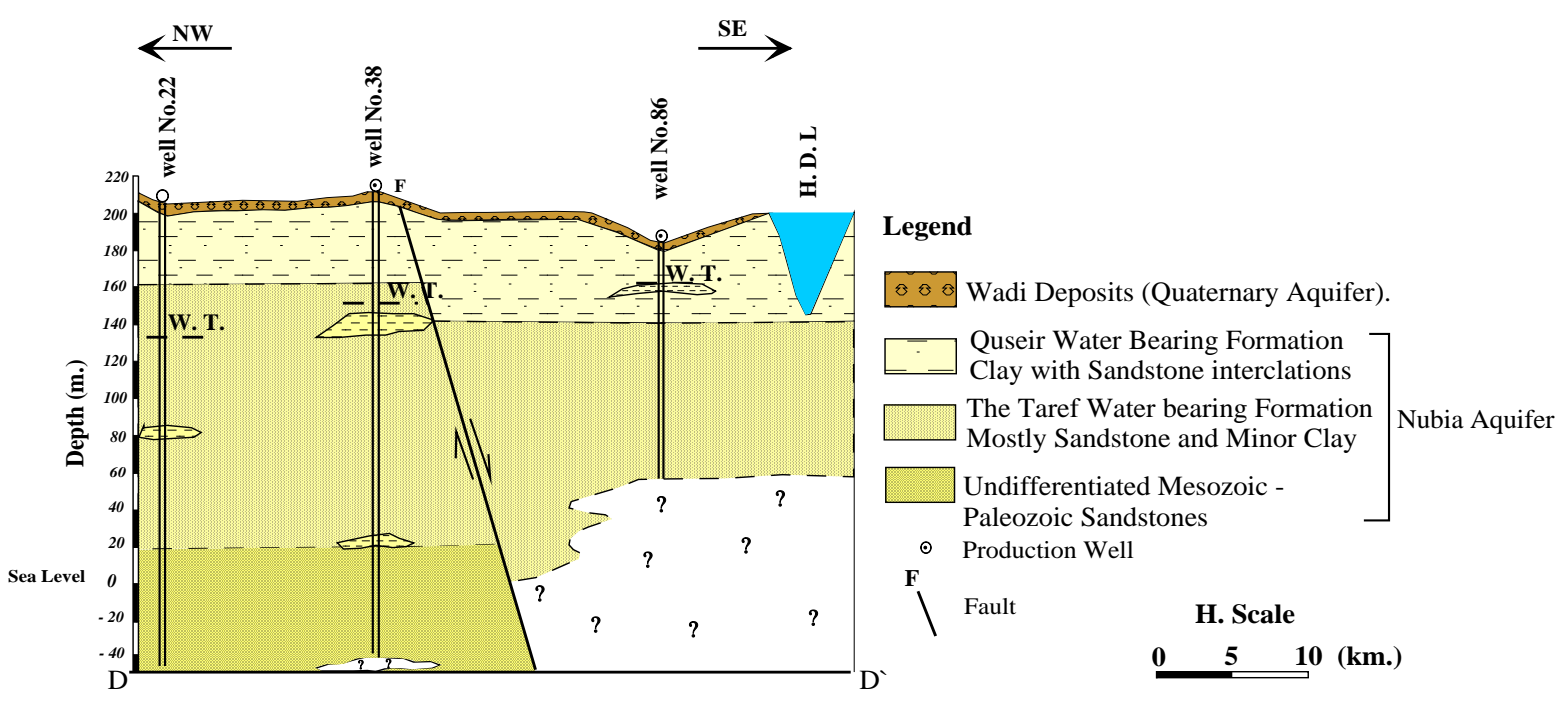

Figure 10. Hydrogeological cross section (D-D'). 
from 135.09 m. a.s.l in the northwest at well no. 22 to 161 m.a.s.l in the southeast at well no. 86 (Figure 10). The Nubia aquifer ranges between $70 \mathrm{~m}$ at (Khor Galal well Figure 7) and $230 \mathrm{~m}$ (well no. 3) as shown in (Figure 9). The saturated water thickness of the Nubia aquifer across the hydrogeological sections ranges between $70 \mathrm{~m}$ in the NE to $210 \mathrm{~m}$ in the SW (Figure 7); $90 \mathrm{~m}$ in the $\mathrm{W}$ to $170 \mathrm{~m}$ in the $\mathrm{E}$ (Figure 8); $134 \mathrm{~m}$ in the NW to $230 \mathrm{~m}$ in the SE (Figure 9) and $102 \mathrm{~m}$ in the SE to $192.0 \mathrm{~m}$ in the NW as shown in (Figure 10). According to the above described water bearing formations the saturated thickness of the Nubia aquifer ranges between $70 \mathrm{~m}$ in the NE at Khor Galal well (Figure 7) and $230 \mathrm{~m}$ in the SE at well no. 3 as shown in (Figure 9).

\subsection{Hydraulic Properties of the Nubia Aquifer}

In order to define the hydraulic parameters of the aquifer system in the area, pumping tests at 14 production wells were carried out. The location of these wells is shown in Figure 11. Observation wells were used to monitor the drawdown around the pumping wells to determine the transimissivity and the hydraulic conductivity of the water bearing sediments. The method of [22] [23] are used in the present study. Based on the analysis of the pumping test data, the transimissivity and the aquifer hydraulic conductivity are estimated. Table 1 shows the average transimissivity values estimated at the 14 pumping wells and their classification regarding the aquifer potentiality as shown in Figure 12.

From Figure 12 and Table 1, it is concluded that the aquifer potentiality is increasing toward the Lake north of Khor Toshka while it is decreasing in the other direction. This is probably due to high hydraulic conductivity and aquifer thickness in the area northeast of Khor Toshka and at west of Garf Hussein. The analysis of pumping test data indicated that the hydraulic conductivity of the aquifer in the area ranges between 12.73 and 0.9 $\mathrm{m} /$ day at Amada and Toshka wells, respectively. Table 2 shows the calculated hydraulic conductivity at the stu-

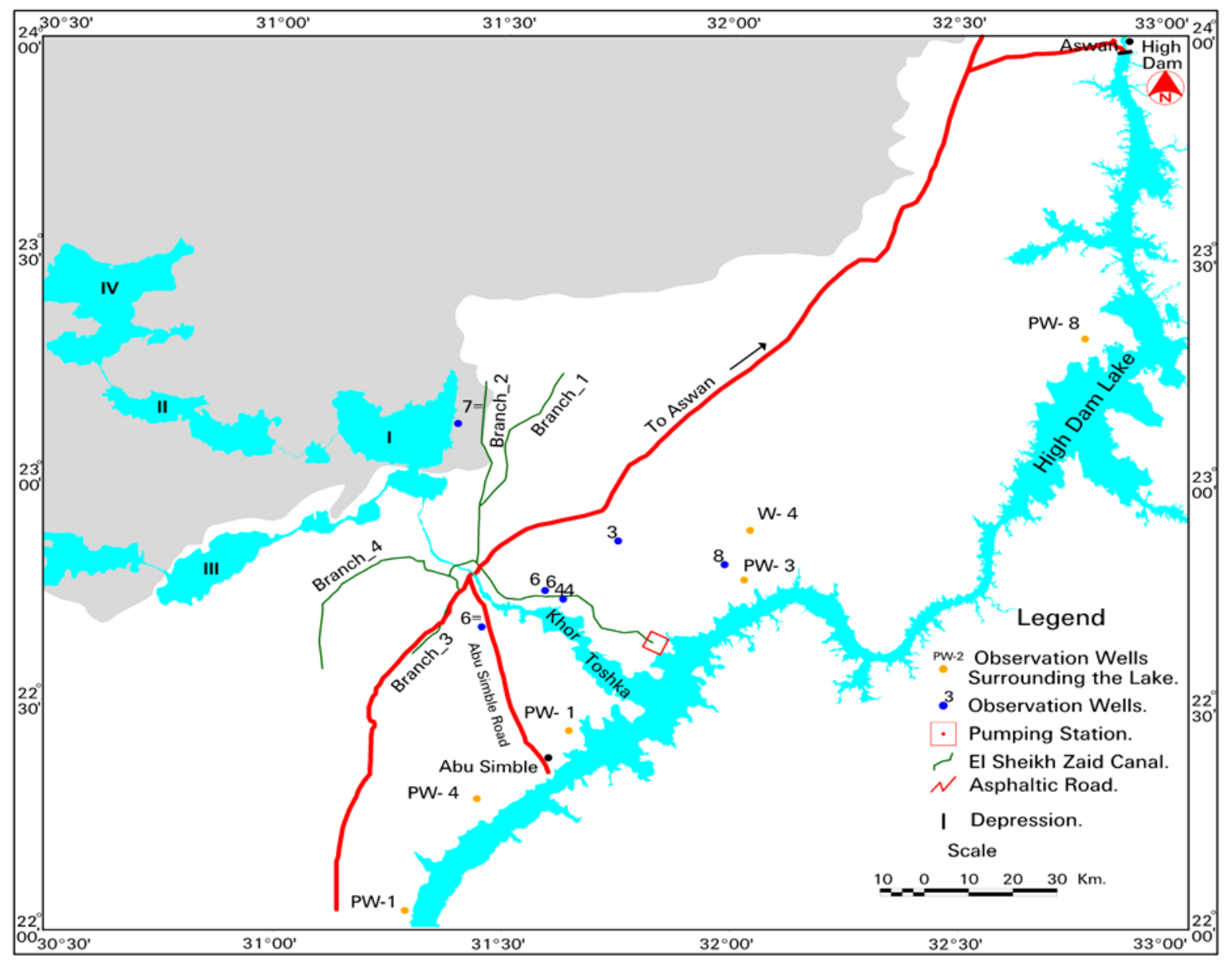

Figure 11. Location map of the pumping test wells in the area to the west of High Dam Lake. 
Table 1. Classification of nubia aquifer potentiality based on transimissivity values.

\begin{tabular}{ccc}
\hline Potentiality & Well No. & Transimissivity values $\left(\mathrm{m}^{2} /\right.$ day $)$ \\
\hline \multirow{3}{*}{ High potential } & 22 & 936.5 \\
& 23 & 1172 \\
& 46 & 726.40 \\
& Khor Galal & 583.4 \\
& Katta & 1378 \\
& Toshka & 1557.8 \\
& 86 & 347.7 \\
Moderate potential & 60 & 459.5 \\
& 54 & 360.2 \\
& Kalabsha & 408.8 \\
& Garf Hussein & 472.5 \\
& Um Simble & 377.4 \\
& Amada & 122.1 \\
\hline
\end{tabular}

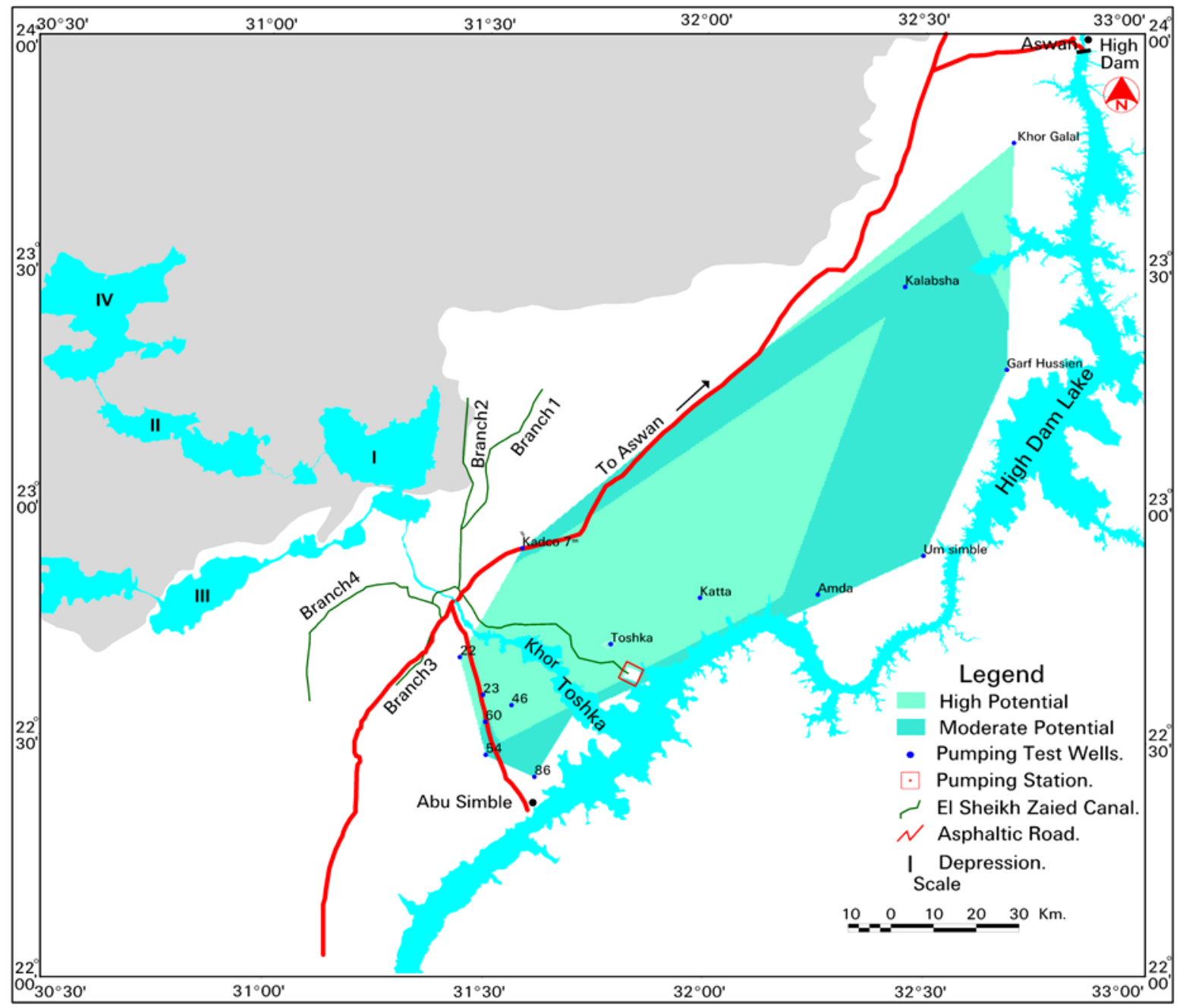

Figure 12. Groundwater potentiality map in the area of High Dam Lake.

died wells.

The calculated hydraulic conductivity indicated that it increases in the northeastern part in the area of the study whereas and decreases in the middle and south parts in the area. This is definitely related to the aquifer li- 
Table 2. The calculated hydraulic conductivity.

\begin{tabular}{ccc}
\hline No. & Well No. & $\begin{array}{c}\text { Hydraulic } \\
\text { Conductivity } \\
\text { (K in m/day). }\end{array}$ \\
& & 10.90 \\
1 & Khor Galal & 2.75 \\
2 & Kalabsha & 2.74 \\
3 & Garf Hussein & 2.4 \\
4 & Um Simble & 0.9 \\
5 & Amada & 11.27 \\
6 & Katta & 12.73 \\
8 & Toshka & 3.99 \\
9 & Kadco-7 & 3.15 \\
10 & 86 & 3.24 \\
11 & 60 & 2.34 \\
12 & 54 & 5.64 \\
13 & 22 & 8.31 \\
& 23 & 4.46 \\
\hline
\end{tabular}

thology where thick clay succession exists in the middle and southern parts of the area.

\subsection{Groundwater Flow}

In order to determine the groundwater flow in the Nubia aquifer, water levels at the existing wells tapping the aquifer are collected during December 2006 and mapped using GIS and given in Figure 13. Generally groundwater in the Nubia aquifer is flowing from east to west and is greatly affected by the basement complex uplift (which acts as a barrier for groundwater flow), the local geological structure (i.e., fault systems), the high thickness of the impervious beds (i.e., clay and shale) and their hydrologic properties are the main factors controlling the groundwater flow.

\subsection{Changes in Groundwater Level}

In order to investigate the changes in groundwater level in the area, data concerning the water elevation in the existing wells were collected and analyzed during the period from 1998 to 2006 (Figure 14). Groundwater extracted from these wells is used for land reclamation in the areas. The extracted water is used to supplement the surface water for land reclamination in the area. It is noticed that there is a drop in water levels during that period ranging between 1 to 14 meter in the study area (Figures 15-17). The highest drop in water level is observed at well No. 4 (drop is estimated as 14 meter) reflecting the high rate of extraction. Such drop indicated that the extraction rate of water is much higher than the recharging rate. The drop is expected to continue with the continuous extraction of groundwater leading to aquifer depletion in the area.

\section{Relation between Groundwter and Surface Water}

The relation between the groundwater in the aquifer and HDL is very complicated and was dealt by many authors e.g. [24]-[28]. After the construction of the High Aswan Dam and the formation of High Dam Lake, the yearly cycle of groundwater fluctuation was changed due to rapid variation in lake water levels. [24] indicated that, there is a direct connection between surface water level and groundwater level with time lag according to the distance of wells from the lake and the nature of the water bearing formation. [25] indicated that the area west of Toshka and west Adindan are affected by the fluctuation of High Dam Lake, whereas, at Toshka depression and Kurkur area, no affect of the fluctuation of High Dam Lake on groundwater was observed. [26] indicated that, there is a hydraulic connection between the water level in High Dam Lake and groundwater aquifer at Amada Road area. This hydraulic connection is effective for less than $38.5 \mathrm{~km}$ from High Dam Lake. [27] indicated that there is a hydraulic connection between the water level in High Dam Lake and groundwater aquifer. It was found that the hydraulic connection is very effective within a distance of about $58.32 \mathrm{~km}$ from the lake.

In the present study, in order to investigate the change in groundwater regime and its influence by the High Dam Lake (HDL), the available data of surface water of the lake during (1999-2002) were collected. The loca- 


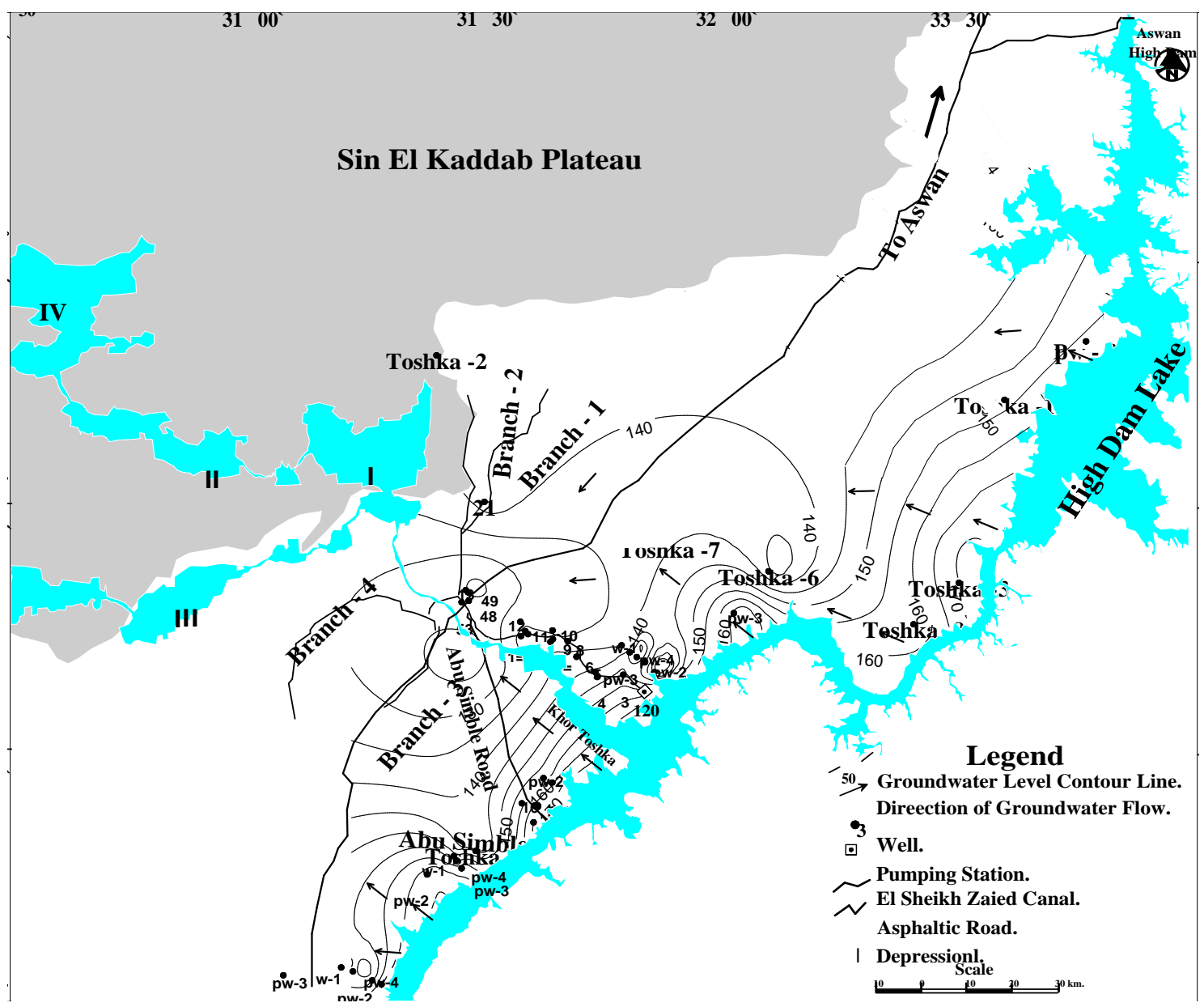

Figure 13. Water table map (December 2009) in the study area showing the direction of groundwater flow of the Nubia Aquifer.

tion of these observation wells is shown in Figure 14. To provide a good record of the response of water levels in the Nubia Formation to changes in water levels in High Dam Lake, data of groundwater levels were collected from 12 deep and shallow piezometers. Six piezometers are distributed perpendicular to the High Dam Lake while the others are scattered in the study area. The relation between groundwater level fluctuations in these wells is compared with the fluctuation of the water level in the High Dam Lake. The distance between the observation wells and the relation between the fluctuations of groundwater levels relative to the fluctuation of water in the HDL is given in Table 3.

In summary, the analyses of the above mentioned data (Table 3) indicated that the influence of water of the lake on groundwater level in the area is observed only at well no. PW-4 and well no. PW-1. The two wells are located at 10.78 and $2.12 \mathrm{~km}$ from the lake shore line respectively. On the other hand, there is no relation between the groundwater in the aquifer and the changes in water levels of the lake in the other observation wells. This is mainly due to the vertical and lateral distribution of various lithologic units and the existence of tectonic barriers such as faults or volcanic (sills).

\section{Seepage from the Lake to Adjacent Aquifers}

Estimation of the water seepage from High Dam Lake into the adjacent aquifers is one of the main factors influencing the water balance of the lake. In the present study, the discharge or the seepage from High Dam Lake to the adjacent aquifers along the shoreline of about $865 \mathrm{~km}$ is estimated by Darcy's law as. 


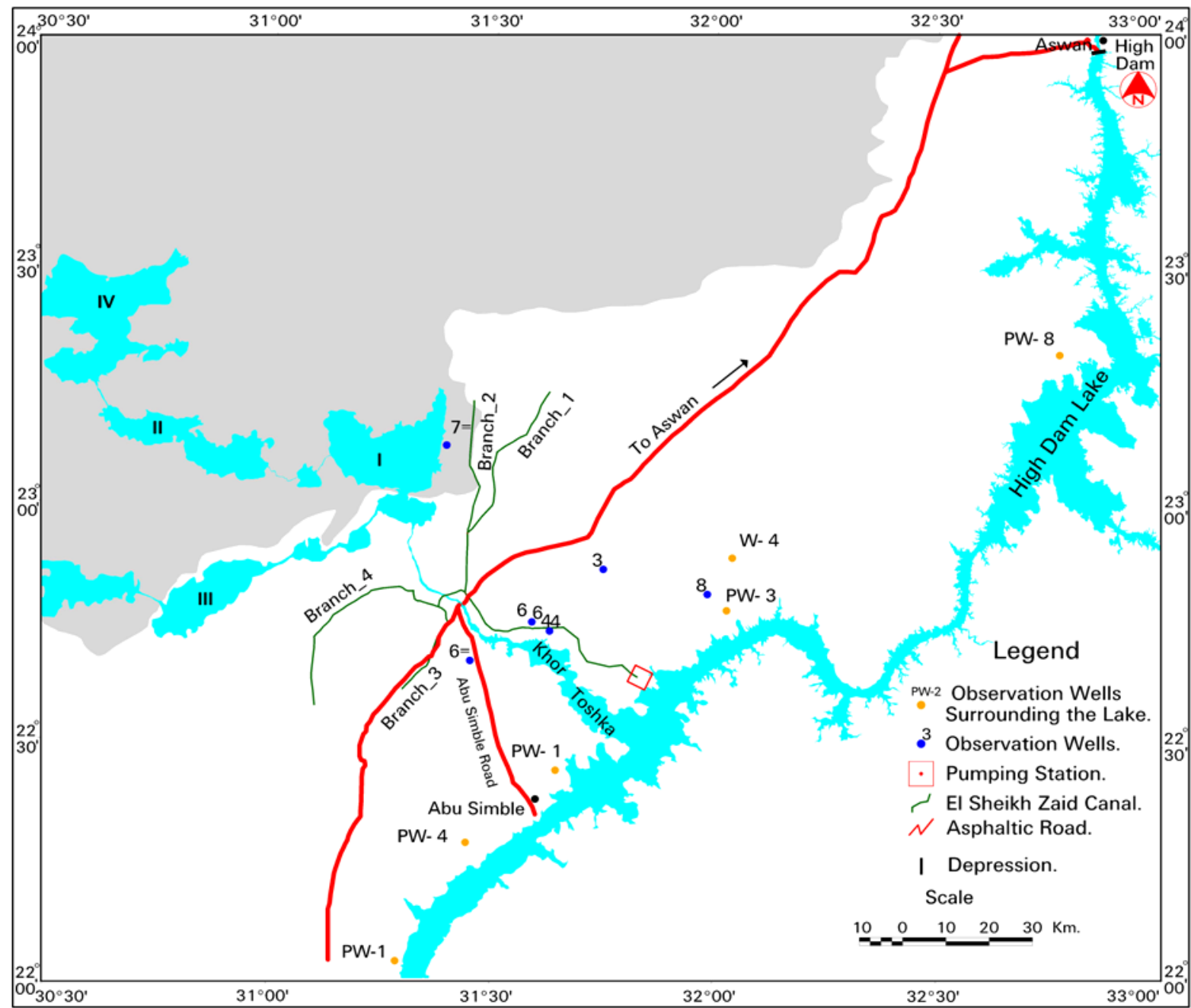

Figure 14. Location map of the observation wells in the study area.

$$
Q=K I A
$$

where:

$Q=$ the discharge in $\mathrm{m}^{3} /$ day.

$K=$ the hydraulic conductivity in $\mathrm{m} /$ day.

$A=$ the area of discharge in $\mathrm{m}^{2}$.

$I=$ the hydraulic gradient.

In order to estimate the seepage toward the study area (west of the lake), the shore line of the lake is divided into six sections based upon the morphology of the lake and the distribution of the observation wells (Figure 18). Applying the above mention Darcy's law on the six sections using the available data of 2006, indicated that the seepage values are to be $238.13 \times 10^{6} \mathrm{~m}^{3} /$ year or $275331.3 \mathrm{~m}^{3} /$ year $/ \mathrm{km}$. It is important to mention that the value of the seepage depends on the changes in the levels of groundwater in the aquifer and surface water of the lake. Therefore, the value of seepage will change from season to another.

\section{Geo-Enviromental Impacts}

The development components on Toshka Project include the cultivation of about $2260 \mathrm{~km}^{2}$ of the desert lands using surface water from the High Dam Lake in the "Toshka Project” in addition to groundwater extraction from the Quaternary and Nubia aquifers to accelerate the development of the area. Several geo-environmental impacts are expected to take place on the area. 


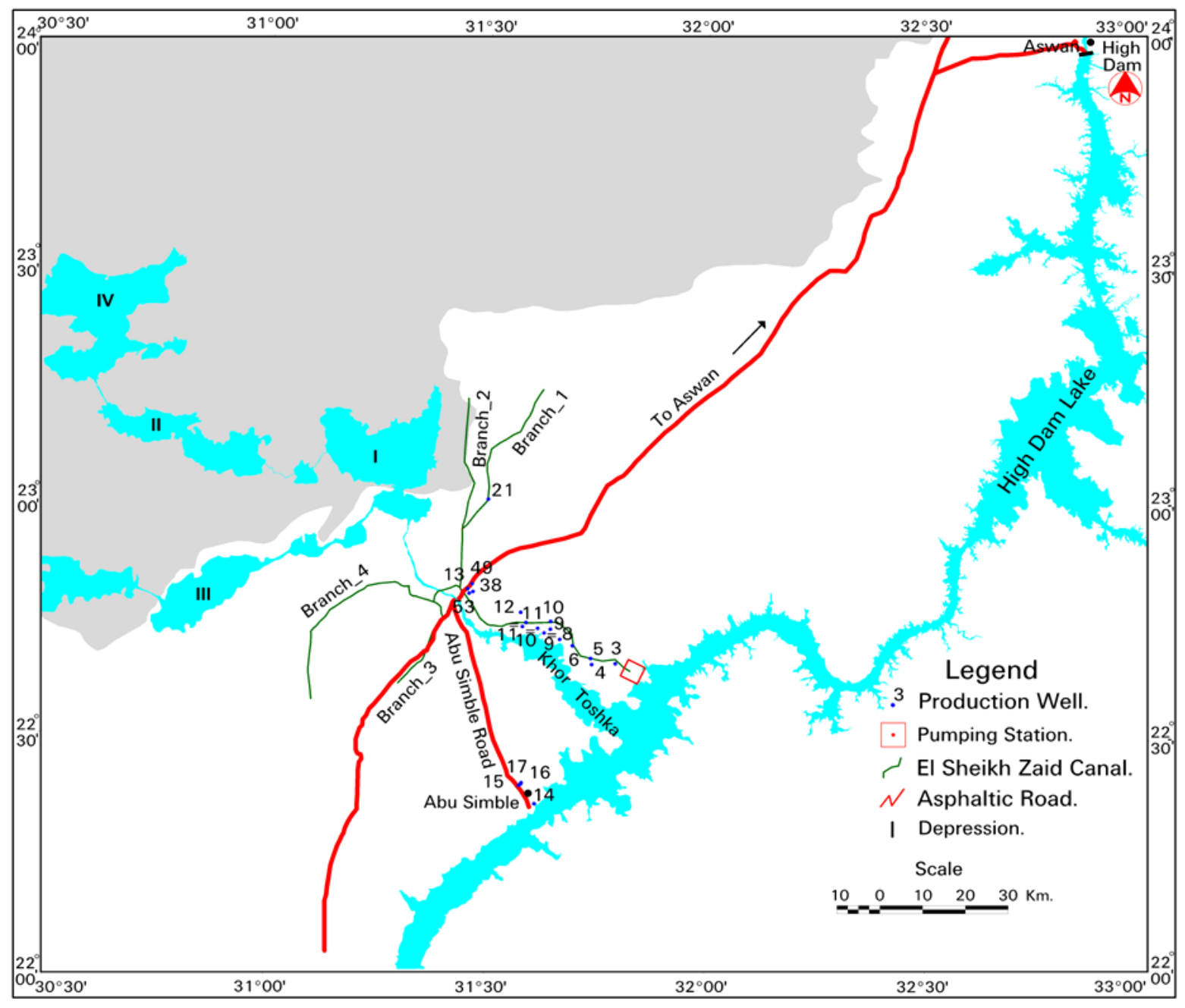

Figure 15. Location map of the production wells in the area to the west of High Dam Lake.

As indicated in hydrogeological setting the groundwater aquifer are subjected to over pumping to meet the overgrowing agricultural development in the area. Continuous drop in groundwater level is observed in the area. The average drop in the groundwater is ranging between 1 and 14 meters in some areas (Figure 17). This is clear indication of the fact that the pumping from groundwater in the areas is much higher than the replacement rate of the aquifer. If the current groundwater extraction rate will be continuing in the future, the groundwater chemistry in the areas is expected to be more saline. It is expected that the groundwater quality would be deteriorated due to the increase in the salt contents in groundwater.

The irrigation development in the area will complicate the distribution and movement of groundwater in the vicinity of the proposed area for development. In particular, many proposed areas with small aquifer thickness will be saturated with the introduced water. The heads in those areas will continue to increase, resulting in potential changes in the groundwater flow directions. Changes were observed in the water flow directions between the HDL and the aquifer in some areas (particularly in areas where there is a direct hydraulic connection between the lake and the aquifer). Hence, at the proposed area for development, the flow of water takes place from the aquifer to the lake. If the groundwater extraction will continue, a reverse direction of flow will occur. Thus, the contamination of the HDL resulting from the agricultural drainage would be expected. One the other hand, it is expected that the recharge from the application of surface water for irrigation in the area will be minimal (as the basin irrigation system will not be applicable). The present study indicated that the aeration zone of the area is ranging between 65 to 10 meters and the thickness of this zone is decreasing towards the east and west (Figure 19). 


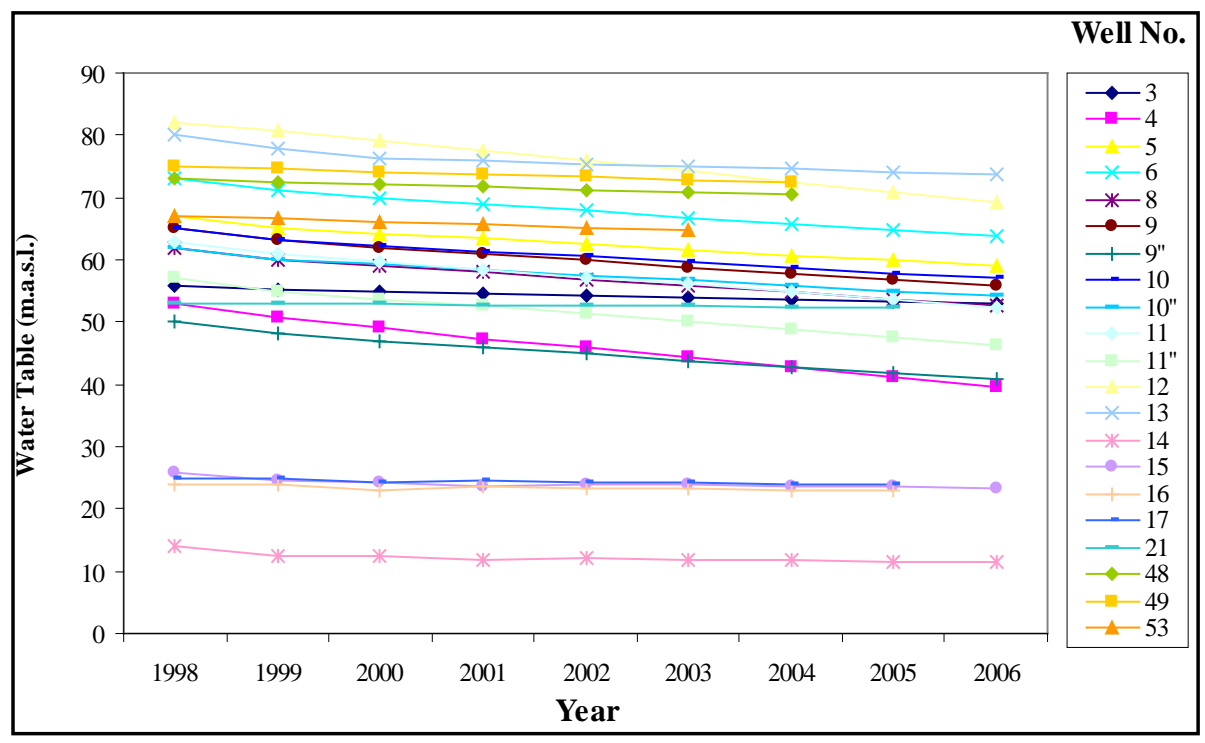

Figure 16. Change in groundwater levels of some production wells from 1998 to 2006 (See Figure 15 for well location).

\section{Well No.}

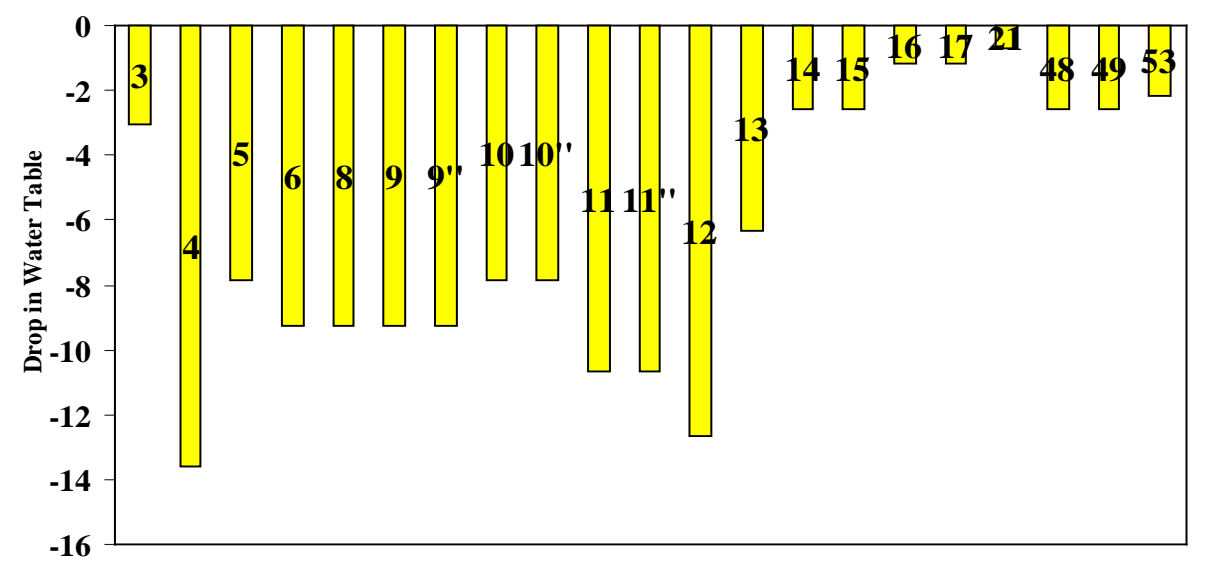

Figure 17. Average drop in groundwater level of some wells from 1998 to 2006 (See Figure 15 for well location.

Table 3. Summary of the relation between surface water of the HDL and groundwater levels in the study area.

\begin{tabular}{ccc}
\hline $\begin{array}{c}\text { Observation } \\
\text { well No. }\end{array}$ & Distance from the Shoreline in km & The relation \\
Pw-8(Garf Hussein) & 11.77 & Negative \\
Negative & Negative \\
PW-4(Afiea West) & 52.81 & Positive \\
PW-1(Abu Simble) & 6.36 & Positive \\
PW-4(Adindan West) & 2.94 & Negative \\
PW-1(Argeen West) & 10.78 & Negative \\
8 & 59.12 & Negative \\
3 & 82.95 & Negative \\
4 & 44.01 & Negative \\
Negative & Negative \\
$7^{=}$ & 53.24 & 19.12 \\
\end{tabular}




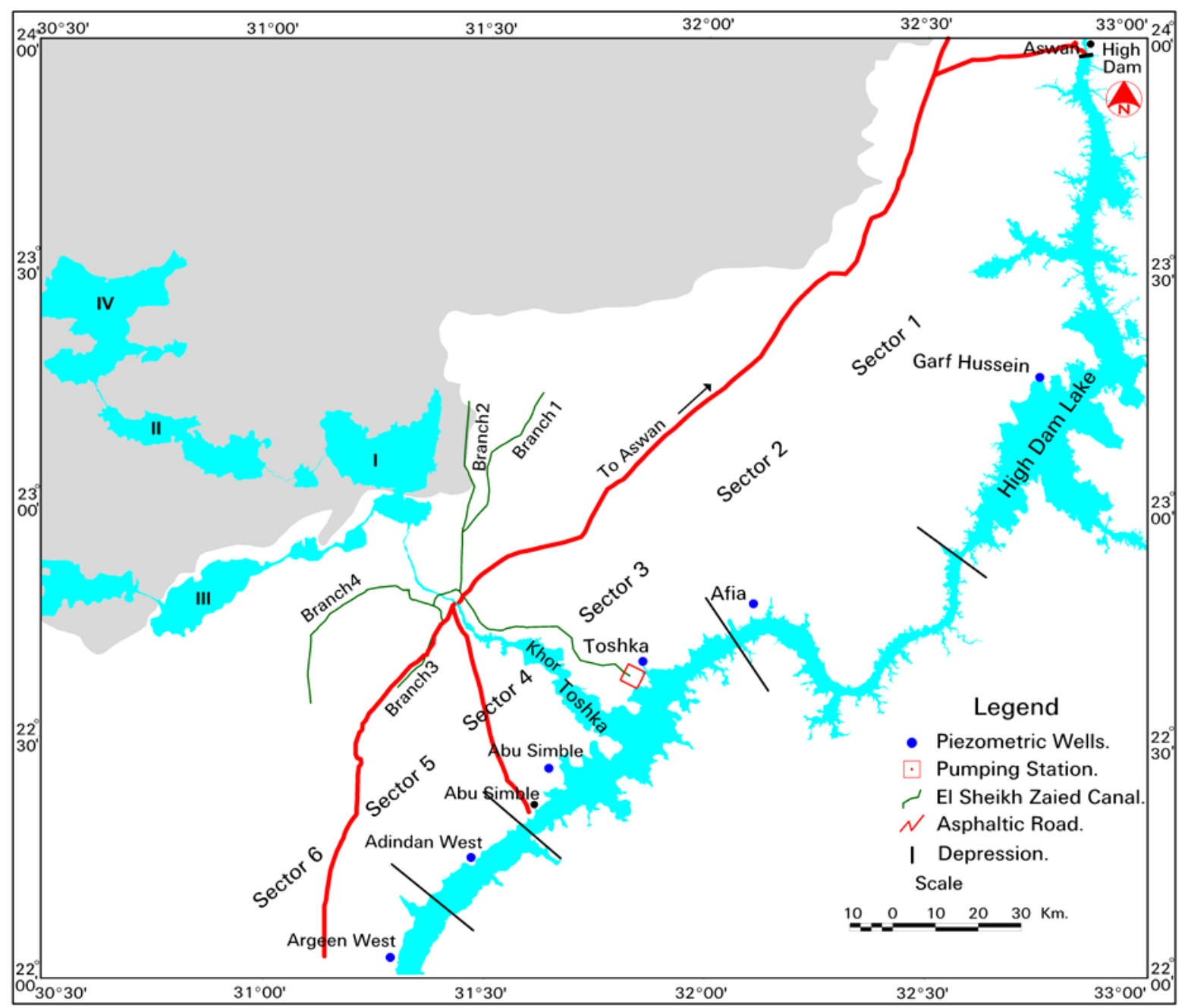

Figure 18. Location of the sectors for estimating the seepage for the High Dam Lake.

It is expected that using the groundwater as source of irrigation water would lead to increasing the soil salinization due to the high rate of evaporation rate in area and the high content of salt in groundwater especially if no flushing system is applied to wash the salts from the fields. Again, using the surface water for cultivation in the area, soil salinization of the top layer due to the soil in the area is mostly clay, and will cause a great problem on the fertility of the soil.

As mentioned earlier, there is an observed drop in groundwater levels due to the over pumping in the area. Thus, if the over pumping will continue, the flow of water between the groundwater aquifer and the lake will be from the lake to the aquifer and accordingly no impact on the water quality of the lake would take place. On the other hand, once the project will be in full operation and surface water will be used for irrigation, it is expected that the groundwater level will continue to rise. This will be accompanied by the reverse flow of groundwater water (i.e. from the aquifer to the lake) and accordingly the lake water may be subjected to water quality deterioration due to the associated agricultural salt drainage to the lake. Considering the fact that the applied irrigation system of the project is the sprinkler or drip type, such impact will be limited, still the problems of the type of soil and the salts resulted from the plantation would find some kind of remedy. It is also important to mention that the land reclamation of the proposed project $\left(2260 \mathrm{~km}^{2}\right)$, once it is fully cultivated, will have an impact on the climate conditions in the area. This impact will result in reducing the temperature rate over the area and thus reducing the evaporation rate from the lake. This will have positive impact on the water loss from the surface water body (HDL). 


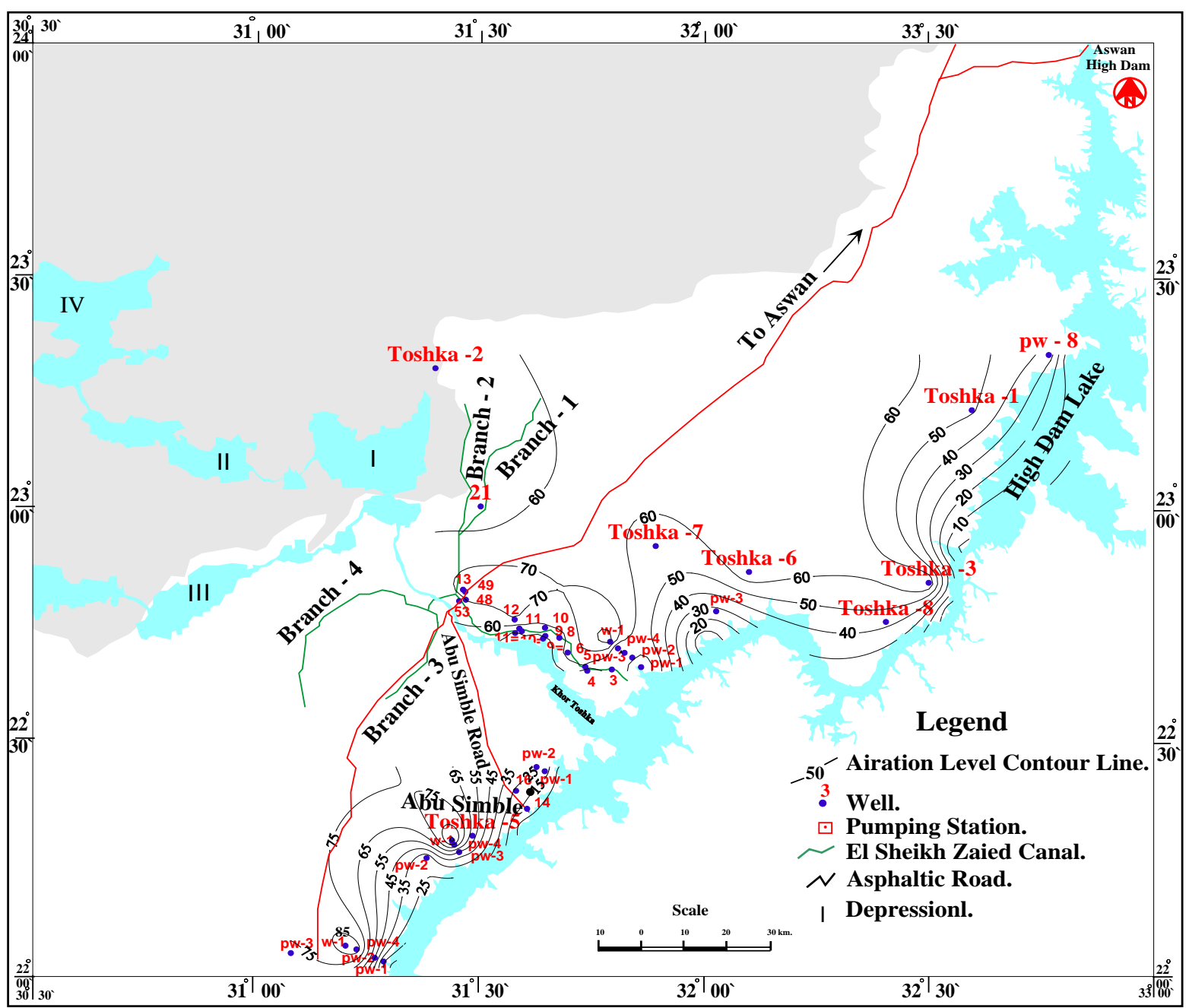

Figure 19. Aeration zone in the area to the west of High Dam Lake.

\section{Conclusions}

The study area occupies the south western corner of the Western Desert of Egypt. It is located west of the High Dam Lake, between latitudes $22^{\circ} 00^{\prime}-24^{\circ} 00^{\prime} \mathrm{N}$ and longitudes $30^{\circ} 30^{\prime}-33^{\circ} 00^{\prime} \mathrm{E}$. It is covering an area of 455,580 $\mathrm{km}^{2}$. The study area belongs to the arid region of North Africa where it is generally characterized by long and hot summer and worm winter with low rainfall. The geomorphic units of the study area include six geomorphological namely; denudational landforms, structural denudational landforms, fluvial landforms, volcanic landforms, landforms related to groundwater with spring mounds and Aeolian landforms.

The exposed rock units in the study area range in age from Pre-Cambrian to Quaternary. They are subdivide lithostratigraphically into the following rock units arranged from base to top Pre-Cambrian (Basement Rocks), Paleozoic Rocks (the Wadi Malik Formation, the Gilf Formation. Mesozoic Rocks (the Abu Ballas Formation, the Burg Formation $\equiv$ El Sabaya Formation, the Bahariya Formation, the Nubia Formation), Cenozoic Rocks (the Kurkur Formation, the Garra Formation, the Dungul Formation, the Volcanic Rocks (Basalt), and the Quaternary Deposits (Sand Dunes and Sand Sheet, Chalcedony Playa Deposits, Calcite Deposits, Fresh Water Limestone, Tufa, and Piedmont Gravels).

The area is dominated by extensional tectonics in a stretch of $350 \mathrm{~km}$ from $\mathrm{N}$ to $\mathrm{S}$ and of over $700 \mathrm{~km}$ from $\mathrm{E}$ to $\mathrm{W}$. Some of the faults herein, extend for huge distances in-between the Red Sea and the Atlantic Ocean, e.g. Guinea-Nubia lineament. Along some of these mega faults, crustal seismicity is high along with volcanicity in the area, extend through a long span of time in-between the Cambrian and Recent. The dominant seismicity of 
this region is a result of ruptures occurring along distinct fault systems.

The Toshka project aims to reclaim about $2260 \mathrm{~km}^{2}$ of the desert lands in its first stage. The project is located in a portion of Egypt's Western Desert known as the Toshka Depression. Its basic premise is simple: using the natural Nile over flow phenomenon, to pump water out of High Dam Lake and, through gravity, to be used for reclamation of desert area in the southern part of Egypt. With the new Toshka project, the Egyptian Government plans on taking some 5000 million $\mathrm{m}^{3}$ of water out of High Dam Lake year.

The hydrogeological investigation in the area indicated that the water bearing formation in the area is represented by the two main aquifers; the Quaternary and the Nubia aquifers. The Quaternary aquifer is composed of sandy facies mixed with clay deposits; it is of reduced thickness, ranges between 5 and $10 \mathrm{~m}$. The groundwater of this aquifer is of limited quantity and of brackish water quality. The Nubia aquifer is the main groundwater aquifer system in the area. The aquifer is of multilayered nature and represents the eastern fringes of the multilayered artesian aquifer of the Western Desert of Egypt. In Toshka area the aquifer system is composed of three horizons (Quseir, Taref and undifferentiated Meszoic-Paleozoic sandstone) partially separated by two confining horizons. The hydrogeological section constricted for in area indicated that, the saturated thickness of the Nubia aquifer ranges between $70 \mathrm{~m}$ in the northeast to 230 in the southeast.

The water levels in the Nubia aquifer differ from one locality to another. The result indicated that it is ranges between 112.14 m.a.s.l at the part of the study area and 161 m.a.s.l at the southeast part of the area. According to above described water bearing formation the saturated thickness of the Nubia aquifer ranges between $70 \mathrm{~m}$ in the NW at (Khor Galal well) and $230 \mathrm{~m}$ in the SE (well no. 3), respectively.

The analysis of the 14 pumping test data carried out in the area indicated that the aquifer potentiality is increasing toward the Lake north of Khor Toshka while it is decreasing in the other direction. This is probably due to high hydraulic conductivity and aquifer thickness in the area northeast of Khor Toshka and at west of Garf Hussein. The hydraulic conductivity of the aquifer in the area ranges between 12.73 and $0.9 \mathrm{~m} / \mathrm{day}$. The calculated hydraulic conductivity is increasing toward the northeastern part in the area of study whereas it decreases in middle and south parts in the area. This is definitely related to the aquifer lithology where thick clay succession exists in the middle and southern parts of the area.

Generally, the direction of the groundwater flow in the area is greatly affected by the basement complex uplift (which acts as a barrier for groundwater flow), the local geological structures (i.e., fault systems), the high thickness of the impervious beds (i.e., clay and shale) and their hydrologic properties are the main factors controlling the groundwater flow. The study revealed that the groundwater in the Nubia aquifer is flowing from west to east. Groundwater extraction is being carried out in the area since the 1990's, to supply the surface water for land reclamation. It is noticed that there drop in water levels during that period ranging between 1 and 14 meter. Such drop indicated that the extraction rate of water is much higher than the recharging rate. The drop is expected to continue with the continuous pumping of groundwater leading to aquifer depletion in the area so the flow of water is from east to west i.e. from the lake to the aquifer.

The analyses of the fluctuation of the groundwater level relative to the seasonal change in the water level of the HDL indicated that the influence of water of the lake on groundwater level in the area is noticed only in the observation wells located at a distance of less than $10 \mathrm{~km}$ from the lake shore line. On the other hand there is a relation between the groundwater in the aquifer and the changes in water levels of the lake in the other observation wells. The controlling factors for the flow of water between the lake and the aquifer are governed by the high water levels in both, the vertical and lateral distribution of various lithologic units and the existence of tectonic barriers such as faults or volcanic occurrences.

Applying Darcy's law to estimate the seepage loss from the HDL carried out on six profiles at the lake indicated that the seepage values are to be $238.13 \times 10^{6} \mathrm{~m}^{3} /$ year or $275331.3 \mathrm{~m}^{3} /$ year/ $\mathrm{km}$. Since in general the level of water in the aquifers is low than in the lake.

If the existing scheme of over pumping will continue, the flow of water between the groundwater aquifer and the lake will be from the lake to the aquifer and accordingly the impact on the water quality of the aquifer would take place. On the other hand, once the project will be in full operation and surface water will be used for irrigation, it is expected that the groundwater level will continue to rise; this will be accompanied by the reverse flow of groundwater. It is also expected that the reclamation of the whole proposed area $\left(2260 \mathrm{~km}^{2}\right)$ will have an impact on the climatic condition in the area. The whole project is governed by flushing the salt from the plantation and the good soil in the area. 


\section{References}

[1] Zaki, S.R. (2009) Geo-Environmental Impact of the Aswan High Dam and Reclamation Projects on the Groundwater Condition in the Area West of the High Dam Lake. Ph.D. Thesis, Sohag University, Sohag.

[2] Osman, R.A., Abdel Moneim, A.A. and Zaki, S.R. (2008) Landscape Evolution of the Area of Nasser Lake since the Oligocene. The 4th International Conference on the Geology of the Tethys, Cairo University, Cairo, 24-26 January 2008, 103-118.

[3] Issawi, B. (1968) The Geology of Kurkur-Dungul Area. Geological Survey, Paper No. 46, Egypt, 102 p.

[4] Issawi, B. (1971) Geology of Darb El Arbain, Western Desert, Egypt. Annals of the Geological Survey of Egypt, 1, 5398.

[5] Issawi, B. (1978) Geology of Nubia West Area, Western Desert. Annals of the Geological Survey of Egypt, III, 237-253.

[6] Osman, R.A. (1992) Contribution to the Geology of the Area Southwest of Aswan. Ph.D. Thesis, Benha University, Egypt, 241.

[7] Issawi, B. and Osman, R.A. (1993) Tectono-Sedimentary Synthesis of the Paleozoic Cretaceous Clastics, Southwest Aswan, Egypt. Journal of Sedimentlogy, 1, 11-21.

[8] Issawi, B. and Gayed, B. (2011) Anogenic and Orogenic Plumes in Egypt. Annals of the Geological Survey of Egypt, XXXI.

[9] Guiraud, R., Issawi, B. and Bellion, Y. (1985) Les Lineaments guineo Nubians un trait structural majeur a I'echelle de la plaque africaine. C. R. Acad. Sc., London, Special Publication No. 32, 217-229.

[10] Youssef, M.I. (1968) Structural Pattern of Egypt and Interpretation. American Association of Petroleum Geologists, 52, 601-614.

[11] Barakat, M.G. and El Ashri, A.H. (1972) Airphoto Interpretation of Some Structural Features in the Area South West of Aswan Egypt. The Journal of Geology, 16, 247-254.

[12] Robinson, C.A., Werwer, A., El-Baz, F., EL-Shazly, M., Fritch, T. and Kusky, T. (2007) The Nubian Aquifer in Southwest Egypt. Hydrogeology Journal, 15, 33-45. http://dx.doi.org/10.1007/s10040-006-0091-7

[13] Thorweihe, U. and Heinl, M. (1993) Groundwater Resources and Management in Southwest Egypt. Catena Supplement, Biomineralization Processes of Iron and Manganese. Berliner Geowissenschaft Abhand, 2, 99-121.

[14] Sabed, S.S and Zeid, A.M. (2003) Contributions to the Hydrogeology of Nubian Sandstone Aquifer in East El-Oweinat Area, South Western Desert, Egypt. Isotope and Radiation Research, 33, 11-177.

[15] Thorweihe, U. (1990) The Nubian Aquifer System. In: Said, R., Ed., The Geology of Egypt, Balkema, Lisse, The Netherlands, 601-614.

[16] El-Mongy, S.A., Awad, M.A. and Aly, A.I.M. (2000) Environmental Isotope and Natural Radioactivity Assessment of Toshka Area, South Nile Valley, Egypt. Arab Journal of Nuclear Sciences and Applications, 33, 1-16.

[17] Sadek, M.A., Abd El-Samie, S.G., El-Arabi, N.E. and Ahmed, M.A. (2001) Hydrochemical, Isotope and Age Characteristics of the Groundwater in the Nubian Sandstone Aquifer, South Western Desert, Egypt. Isotope and Radiation Research, 33, 161-177.

[18] CEDARE (2001) Regional Strategy for the Utilization of the Nubian. Center of the Environment and Development for the Arab Region and Europe, Cairo.

[19] Fathy, R.G., El-Hefnawy, M.M. and Abdel El-Hamid, A. (2001) Contribution to the Hydrogeology Aspects of the Groundwater Aquifer in Southern Part of Darb EL-Arbeain Area, Southern Portion of Western Desert, Egypt. Al-Azhar Bulletin of Science, 12, 175-194.

[20] Fathy, R.G., Nagaty, M., Abde El-Hamid, A. and El-Gammal, N.M. (2002) Contributions to the Hydrogeology and Hydrochemical Characteristics of the Nubian Sandstone Aquifer in Darb El-Arbeain Area, Southern Portion of Western Desert, Egypt. Al-Azhar Bulletin of Science, 13, 175-194.

[21] Patterson, L.J., Sturchio, N.C., Kennadt, B.M., van Soest, M.C., Sultan, M., Lu, Z.T., Lahmann, B., Purtschert, R., El-Alfy, Z., El-Kalioubl, B., Dawood, Y. and Abdellah, A. (2005) Cosmogenic, Radiogenic and Stable Isotope Constraints on Groundwater Residence Time in the Nubian Aquifer, Western Desert of Egypt. Geochemistry Geophysics Geosystems, 6, 1005.

[22] Theis, C.V. (1935) The Relation between the Lowering of the Pizometric Surface and the Rate and Duration of Discharge of a Well Using Groundwater Storage. Transactions of the American Geophysical Union, 2, 519-524. http://dx.doi.org/10.1029/TR016i002p00519

[23] Jacob, C.E. (1950) Flow of Groundwater in Engineering Hydraulic. John Wiley \& Sons, New York, 321-386.

[24] Abdel Karim, M.H. (1992) Hydrogeological Characteristics of Groundwater Aquifer at Lake Nasser Region. M.Sc. 
Thesis, Cairo University, Cairo, 155.

[25] Omar, H.A. (1996) Hydrogeological and Hydrogeochemical Studies of the High Dam Lake Region and Its Vicinities South Egypt. Ph.D. Thesis, Cairo University, Cairo, 323.

[26] Sallam, O.M. (2002) Groundwater Sustainability for Development Toshka Area. M.Sc. Thesis, Ain Shams University, Cairo, 127.

[27] Kim, J. and Sultan, M. (2002) Assessment of the Long-Term Hydrologic Impacts of Lake Nasser and Related Irrigation Projects in Southwestern Egypt. Journal of Hydrology, 262, 68-83. http://dx.doi.org/10.1016/S0022-1694(02)00013-6

[28] El Sabri, M.A.Sh. (2006) Evaluation and Management of Groundwater Resources in the Area between Abu Simble and Toshka, South Western Desert, Egypt. Ph.D. Thesis, Minoufiya University, Monufia, 192. 